\title{
Surgical emergency: rupture of infected brachial artery pseudoaneurysm
}

\author{
Derek Lim, David Parizh, Vadim Meytes, Anthony Kopatsis
}

General Surgery, NYU Lutheran, Brooklyn, New York, USA

\section{Correspondence to}

Dr David Parizh,

david.parizh@nyumc.org

Accepted 1 May 2017

\section{DESCRIPTION}

A 53-year-old right hand dominant man with a significant medical history of intravenous heroin abuse for over 10 years. He admitted to last injecting heroin this morning into his right arm. Surgical history is significant for traumatic right-hand amputation 10 years ago and multiple right-arm debridements for chronic wound infections from active heroin use. Patient presented to the emergency department with a brisk pulsatile right upper arm bleed. On initial surgical consultation, the patient was found to be hypotensive and tachycardic. Manual pressure was held over a pseudoaneurysm that was noted to be bleeding (figure 1 and video 1). Blood pressure cuff was applied proximal to the bleeding site, and the patient was taken to the operating room for exploration.

In the operating room, a horizontal incision was made along the medial side of the upper arm traversing the bicep groove. Brachial artery and vein as well as median and ulnar nerves were identified and isolated accordingly. Brachial artery pseudoaneurysm was identified and suture ligated. Wound was packed and dressed.

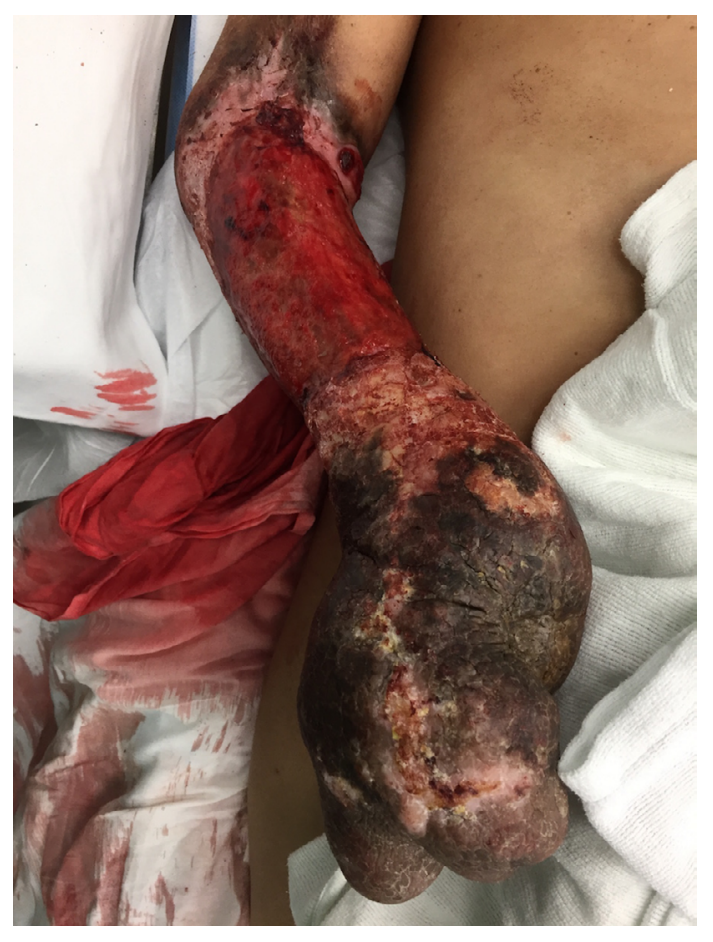

Figure 1 Note the chronic infected wounds and deformed upper extremity from multiple surgical procedures and pre-existing trauma.

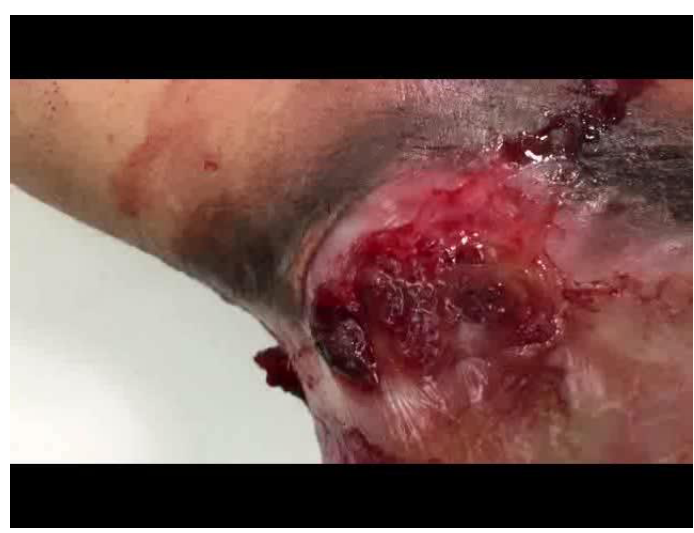

Video 1 Pulsatile pseudoaneurysm with clot over the area of rupture.

Multidisciplinary team and patient discussion decided to proceed with an amputation above the level of the elbow. Subsequent hospital course was uneventful. Patient was referred to a drug rehabilitation facility on discharge.

\section{Learning points}

- The four most common causes of mycotic aneurysm formation include septic emboli arising from cardiac valves, contiguous spread, infection of pre-existing aneurysm and bacteraemia in patients with significant atherosclerotic disease leading to seeding of arteries with subsequent aneurysmal formation.

- Mycotic brachial artery pseudoaneurysms are associated with intravenous drug use, invasive catheterisation procedures and prosthetic valve endocarditis. $^{1}$

- Upper extremity mycotic pseudoaneurysms are only seen in $10 \%$ of cases.

- The prevalence of arterial mycotic pseudoaneurysm is estimated to be about $0.03 \%$ per year. $^{2}$

Contributors DL, DP, VM and AK contributed evenly to the research, conceptualisation, drafting and final approval of the manuscript.

Competing interests None declared.

Patient consent Obtained.

Provenance and peer review Not commissioned; externally peer reviewed.

(c) BMJ Publishing Group Ltd (unless otherwise stated in the text of the article) 2017. All rights reserved. No commercial use is permitted unless otherwise expressly granted. 
Images in...

\section{REFERENCES}

1 Leon LR, Psalms SB, Labropoulos N, et al. Infected upper extremity aneurysms: a review. Eur J Vasc Endovasc Surg 2008;35:320-31.

2 Tsao JW, Marder SR, Goldstone J, et al. Presentation, diagnosis, and management of arterial mycotic pseudoaneurysms in injection drug users. Ann Vasc Surg 2002;16:652-62.

Copyright 2017 BMJ Publishing Group. All rights reserved. For permission to reuse any of this content visit http://group.bmj.com/group/rights-licensing/permissions.

BMJ Case Report Fellows may re-use this article for personal use and teaching without any further permission.

Become a Fellow of BMJ Case Reports today and you can:

- Submit as many cases as you like

- Enjoy fast sympathetic peer review and rapid publication of accepted articles

Access all the published articles

Re-use any of the published material for personal use and teaching without further permission

For information on Institutional Fellowships contact consortiasales@bmjgroup.com

Visit casereports.bmj.com for more articles like this and to become a Fellow 